\title{
Resiliency and Cooperation or Regarding Social and Collective Competencies for University Achievement. An Analysis from a Systemic Perspective
}

\author{
Miriam Aparicio \\ CONICET (National Council for Scientific and Technical Research, \\ Parque General San Martin, Mendoza, Argentina) - Mendoza). Argentina. Lead Researcher. \\ National University of Cuyo, PICTO Project 2016-0008. BID Loan. Argentina.
}

\begin{abstract}
This research is found within the framework of the issue of University Quality. It was carried out using a sample of subjects from 6 different university schools in Argentina who extended their studies (1985-2004). The objective was to determine the factors underlying this extension. The methodology used was quantitativequalitative. The model integrates base variables, pedagogical-institutional variables, structural variables, organizational variables, and psychosocial variables. Among the latter, we focus on Cooperation - nucleus of Resilience - in relation to university success (US), taking into account that cooperation is a social/collective competence which is highly valued in the new organizational models looking toward student success (PISA, 2015; OECD 2018). The results show the impact of this factor on achievement, as well as the importance of building collective competencies.
\end{abstract}

Keywords: cooperation - resiliency - university - extending studies - social and collective competencies

\section{Introduction}

Abrupt changes within the context of globalization, particularly at the social and economic level, demand integrative transformations on the part of labor organizations and educational institutions. In fact, more educated and more resistant human capital is needed (not just in disciplinary terms) in order to face the growing difficulties and demands, as well as the adaptation/reconversion, that innovation requires. And this "human capital" is formed inside socializing educational institutions.

Economic changes imply an important questioning of the traditional organizational model. "Large organizations are no longer seen as 'models of success'. They reduce permanent employees, use provisionary labor (subcontracting) and redesign their limits. They work more with the networking model than with that of the centralized organization. Their system of relations occupies considerable space. The quality and trustworthiness of interactions within the system are a source of competitiveness and wellbeing. In other words, there is a change of model within the workplace organization. The model is no longer based on a position within the company and individual performance, but rather on consistency and the integration of subsystems, on communications between services, beyond those of subcontractors (associations)" (Bernoux, 1995, p.31, cit. por Petit \& Dubois, 1998, p.105).

The global model has changed: today, progress does not happen through specialized activities (Berlinger, 2017: 219-244); on the contrary, development implies rather the exchange and reformulation of specialties. There are new ways of handling human resources, ways which are more participatory and decentralized, and new ways of training based on consulting, coaching and on the transformation of cognitive, social and collective competencies which make employees too agents of 
change. Adaptability to and understanding of a situation occupy a central space. And this requires two new types of abilities: a) theoretical dominance of processes and b) cooperation with team members.

In this context, cooperation becomes a profound necessity (Raus, 1994) for a variety of fields: health, business, education and culture, among others.

\section{General theoretical framework}

\subsection{General issue and related aspects: On Quality, pertinence and prioritized " skills »/competencies}

Here we present the results of research at a national university in Argentina, carried out with individuals who extend their studies (19852004), that is to say, individuals who present "negative performance" at the institutional level, even if this extension, from a personal point of view, corresponds to "reasons" appropriate to the student's level; reasons that could respond to a "choice" and sometimes even accompanied by satisfaction (Lévy-Garboua, 1978, theory of deferred gratification / "patterns of deferred gratification", Aparicio, 2013 $a, b)$. More precisely, this research is part of the general issue of organizational / institutional quality (in this particular case, of the university) where rates of extending studies are very high.

Our research contributes to an understanding of the quantitative factors and captures the qualitative " reasons » underlying the elevated rates of relative failure: only $11 \%$ of students, globally, finalize their studies; $60 \%$ drop out; and $29 \%$ « decide » to extend them ${ }^{1}$. This issue represents a material and human cost in terms of frustration. In effect, among the psychosocial responses that can be observed, we find anomie, emptiness, depression and burnout (Aparicio, 2009 e, f).

The results of previous and complementary research carried out with different university populations (Aparicio, 1995-2016) show that the characteristics of university education -reduced almost to the disciplinary level - are an underlying factor for the aforementioned statistics. In fact, the system very often neglects the formation of additional abilities necessary for both academic and workplace success: communication, coping strategies, resilience, cooperation, problem-solving skills, skills for collaborative work, and the ability to reflect on one's own actions and practices, looking towards change and the new demands.

In other words, despite the need for interdisciplinary and transdisciplinary work (based on the "problems" that our reality presents), the educational system has continued to operate with a structure based on "rigid" courses of study and disciplines with no contact among them. Integral and transversal reforms which make way for additional abilities / competencies and ways of working currently necessary have not been achieved.

On the contrary, other countries have prioritized education and, in the short term, lead the rankings of student performance and system quality (Singapore, Japan, Hong Kong (China), Korea, Canada, Estonia, Finland,...) (OECD, 2017 a and b²; OECD, 2018; PISA, 2015).

Transformation is, therefore, possible and from our perspective implies the articulation of three levels: the educational policy level looking towards the demands of employment of the future, the institutional level and the micro-individual level.

If we focus now on the changes those countries which lead the rankings of student performance in terms of skills / competencies have made, the key centers on: a) a change in positioning of prioritized competencies (OECD, World Economic Forum, 2018; cf. especially the diagram that shows this change, and b) the prioritization of "soft competencies" (defined by the author, for at least the last 15 years, as "social and collective competencies").

\footnotetext{
${ }^{1}$ These percentages, practically without any changes, are still observed today.

${ }^{2}$ Skills ranking for collaborative problem-solving is presented (Average performance for all Pisa participating countries and economies). Cf also OECD (2017a), "Collaborative problem solving", PISA in Focus, No. 78, OECD Publishing, Paris, http://dx.doi.org/10.1787/cdae6d2e-en

We read: In total, 52 countries and economies participated in the 2015 assessment of collaborative problem solving.

OECD countries: Australia, Austria, Belgium, Canada, Chile, the Czech Republic, Denmark, Estonia, Finland, France, Germany, Greece, Hungary, Iceland, Israel, Italy, Japan, Korea, Latvia, Luxembourg, Mexico, the Netherlands, New Zealand, Norway, Portugal, the

Slovak Republic, Slovenia, Spain, Sweden, Turkey, the United Kingdom and the United States. Partner countries and economies: Beijing-Shanghai-Jiangsu-Guangdong (China), Brazil, Bulgaria, Colombia, Costa Rica, Croatia, Cyprus*, Hong Kong (China), Lithuania, Macao (China), Malaysia**, Montenegro, Peru, the Russian Federation, Singapore, Chinese Taipei, Thailand, Tunisia, the United Arab Emirates and Uruguay.
} 
And among these competencies emerges Resilience - a central variable / dimension of this article - a variable which was recently compared by Agacisti et al. for the period 2006-2015, within the framework of PISA (Programme for International Student Assessment). The authors demonstrate that this variable is particularly associated with more positive results for disadvantaged student groups, through a more positive work environment in the classroom ${ }^{1}$, an environment where there is motivation, flexibility and interest (micro level), but also support, advice, guidance and limits set by teachers and the institution itself (meso level).

International results, in line with our research, invite us to: a) establish the importance of this ability, Resilience, and other related competencies in our system, and $b$ ) make a real transfer by taking advantage of programs recently implemented by the Science, Technology and Innovation system (STAN, High-Tech Transfer Services, 2017).

\subsection{Specific theoretical framework regarding central notions: Resilience, Cooperation / Collaboration}

The notion of Cooperation encompasses a very broad semantic field: collaboration, aid, participation, contribution, association and competence. In fact, it is considered a collective competency that prioritizes the relationship level ${ }^{2}$. In addition, it is related to other concepts currently being highlighted in the literature, such as Resilience.

Resilience develops social connections, relationship abilities which will be very useful in the academic world, in the workplace and for life itself. It can be defined as an individual's capacity to react to and to overcome adversity. Agacisti, 2018 defines resilience as "... an individual's ability to prosper despite adverse circumstances" (tn). We read in Koninckx, $2011^{3}$ that "B. Cyrulnik defines resilience as the ability to be successful in life and to develop acceptably despite stress or adversity that normally implies serious negative consequences." Later, a combined definition will be adopted (Vanistaendel, Lecomte, among others): "Resilience is a person's or group's ability to project into the future despite destabilizing events, difficult life conditions or severe trauma, as it moves from the isolated individual to the concept of group and community, highlighting the importance of an individual's interaction with his environment" (t.n). This competency implies a set of qualities that favor a process of successful adaptation and transformation despite risks, the fear of a loss of power and resistance to change. All of these components are important as they relate to success and failure, as they play a fundamental role in cooperation.

\footnotetext{
1 This article defines academic resilience as "...the ability of 15 year-old students from disadvantaged sectors to perform at a certain level on the Program for International Student Assessment (PISA) exams in reading and math, which will prepare them for most all learning opportunities presented to them throughout their lives and which will allow them to play an active role in their communities. Using the most recent PISA data, this document explores the changes in the number of resilient students over time (2006-2015); highlights the importance of school environments and their resources for mitigating the risk of negative performance for disadvantaged students; and identifies the academic factors associated with the probability of academic resilience for socioeconomically disadvantaged students. The analyses reveal that various countries have been able to increase their number of resilient students over time, which reflects improvements in average student performance or a weakening relationship between socioeconomic levels and performance. For the majority of educational systems examined, the probability for academic resilience for disadvantaged students is less in schools where students report a negative classroom climate. The document concludes by exploring the policies and practices of schools for which students report a positive classroom climate. (t.n.)

2 During the last century, emphasis was placed particularly on the socio-cognitive aspects more than on strictly relational aspects. Lazarus and Folkman $(1984,1986)$ define coping strategies as the cognitive and behavioral efforts made by individuals when confronted with situations that are considered emotionally demanding. They can be divided into two groups: strategies centered on problem solving and strategies centered on emotion. Here, individuals must control their emotions in order to reduce anguish (Lazarus, 1994, 2000). Later, Elder and Parker $(1990,1994)$ speak of Confrontation oriented towards avoidance. Currently, though these factors continue to be very important, in our opinion attention should be focused on the relational aspects within the framework of global social crisis (violence, xenophobia, discrimination, etc.).

${ }^{3}$ « B. Cyrulnik defines resilience as 'the ability to succeed, to live and to develop in an acceptable manner in spite of stress or adversity that normally has a serious risk for negative outcome.' Subsequently, a transversal definition will be adopted (Vanistaendel, Lecomte, among others): 'Resilience is the ability of a person or a group to project into the future despite destabilizing events, tough life conditions, and sometimes severe trauma. This is the definition that we will use as a reference, because it moves from the isolated individual to the notion of group and community. The importance of the individual's interactions with the surrounding environment are thereby highlighted' ».
} 
It is not our objective here to linger on the theory of resilience (cf. "founding fathers" in Aparicio $2007 \mathrm{a}, \mathrm{b}$ ), nor on the classical definitions of cooperation (Dubois \& Petit, 1998; Bernaud \& Lemoine, 2000; Sansailieu,1977; Reynaud, 1989; Tersacc, 1992; Landier, 1991; Salais, 1989; Bolstanki \& Thévenot, 1987; Segrestin, 1993, Veltz \& Zarifian, 1989).

Nevertheless, in terms of resilience, it is important to note that the ability to handle new demands, pressures, negotiations, and reformulations of identity is, in the first place, a set of social and intrapsychic processes. It involves the changing of past representations, the retrospective and conscious learning of new models of action and the construction of collective competencies. In addition, as an ability, resilience does not only concem individuals, but also groups (families, communities, businesses or others) $)^{1}$. It leads them to be more flexible in order to be successful in the face of adverse circumstances, thanks to daily practices that promote conscious problemsolving and adaptation to change through the support and reflection developed in one's own action (Hernández, 1998; Puerta de Klinkert, 2002, Koninckx, 2009, 2011; Vanistendael \& Lecomte, 2000; François, 2000; Bernaud \& Lemoine; Shön, 1983, 1992; Argirys, 1982; Argyris \& Shön, 1982. Dans Aparicio 2007 a and b with an in-depth revision of these competencies)2.

In terms of Cooperation / Collaboration, just as with resilience, it is necessary to highlight that these are personal and organizational constructions or co-constructions (Aparicio $2007 \mathrm{a}$ and b). They are systemic in and of themselves.

Before diving into the methodology, we should make some comments regarding the terms Cooperation/Collaboration and Collaborative Work, this last term now being the most used in academic circles, taking into account that this research has been carried out with university students.

In fact, authors such as Maria Angeles Andreu-Andrés (2016), using the experimental model, have demonstrated that there is no difference between the cooperative and collaborative strategy. We read: « The hypothesis that the same educational objective, stated as cooperative or collaborative learning in university teaching settings, does not affect students' perceptions of the learning model guides this study. We analyze the reflections of two student engineering groups that shared the same educational goals implemented through two different methodological active learning strategies: Simulation as a cooperative learning strategy and Problem-based Learning as a collaborative learning strategy. The participants in each group (eighty-five and sixty-five, respectively), as well as the use of the two active learning strategies, either collaborative or cooperative, showed no differences in the results from a qualitative perspective"

Other authors, on the contrary, highlight some subtle differences, and even identify phases of progress in which collaboration would occur previous to cooperation.

To cooperate means to work with another individual so as to make him or her more capable of doing something (typically providing information or resources that they would otherwise be unable to access).

To collaborate means to truly work together with another individual (from the Latin laborare: to work) to achieve something.

On this page ${ }^{3}$, we detail the differences between the two, though this goes beyond the objectives of this article.

We read: "Collaboration and cooperation are words in the English language that have very similar meanings. In fact, there are many learners of English who mistakenly use these words interchangeably as if they were synonyms. Despite overlapping, there are certain subtle differences between the two words that will be highlighted in this article.

What is Collaboration? Collaboration is working together to solve a problem or to achieve a goal. Collaboration takes place between individuals, organizations, and even governments to tackle shared goals and objectives. Sharing of knowledge, expertise, and manual labor may be required in any collaborative venture or endeavor. If a team of scientists is working on a project such as the one that took place at CERN to understand how our universe came into being, we term it a collaborative endeavor. When two countries decide to partner to achieve a shared goal such as fighting terrorism, it is indeed collaboration (...).

\footnotetext{
1 This applies in many disciplines: physics, metallurgy, computer science, ecology, finance, psychology, etc. "In psychology, resilience is the ability to live, to grow, and to overcome the traumatic shocks of adversity" (cf. Koninckx, op cit.).

${ }^{2}$ In order to formulate the theoretical framework for this subproject, it was necessary to review the theory established to date on the topic. Presenting the contributions of each author goes beyond the scope of this article (cf. Aparicio, 2007b).

${ }^{3} \mathrm{https}$ ://www.differencebetween.com/difference-between-collaboration-and-vs-cooperation/Difference Between Collaboration and Cooperation / Consulted May 242018.
} 
What is Cooperation? Cooperation is a word that refers to a process of working in unison to achieve an objective, rather than to work independently to compete with each other. We all know about cooperatives where people pool resources together to have a working system. At the social level, a family is the smallest yet most powerful example of cooperation (...). Without cooperation, it is hard to imagine the world surviving, as nations today are dependent upon each other for most of their resources. We see how countries of the world cooperate with each other whenever there is an epidemic or endemic, or when a calamity or natural disaster strike.

What is the difference between Collaboration and Cooperation? Collaboration is similar to cooperation but takes it to a higher level with the active participation of all members in collaboration; b) When different people or organizations come together to achieve a certain objective, they adopt a shared strategy, shelving their individual approaches. This is what is involved in collaboration. On the other hand, the pooling together of resources and doing one's bit for a shared cause is what characterizes cooperation, c) Cooperation is opposite to standing alone or competing, but collaboration is active participation in a shared endeavor. There is a more formal approach in collaboration than in cooperation".

Globally, the first implies working closely with another, with partners, with the very active participation of both parts. PISA and other programs currently emphasize the importance of collaborative research and of collaborative work and present the question of whether or not schools are prepared for such collaboration. (OECD (2017 b), "Collaborative schools, collaborative students", in PISA 2015 Results (Volume V): Collaborative Problem Solving, OECD Publishing, Paris, http://dx.doi.org/10.1787/9789264285521-12-en.

We read "This chapter - Collaborative schools, collaborative students - examines the impact of positive relationships among and between students, teachers, principals, parents and the wider community on students' proficiency in collaborative problem-solving and attitudes towards collaboration. It tries to answer the question: if all school stakeholders get along well and work together to achieve common goals, does that help students develop their own collaborative problem-solving skills?"

In fact, in 2015 , for the first time since the program went into effect, researchers set out to learn about students' abilities to collaborate to solve problems, beyond their individual abilities, internationally $(\mathrm{Mo}, 2018)^{1}$. This aspect was included due to the fact that it is considered central to the improved development of individual and group potential and to greater development of institutional quality.

"The ability to solve unfamiliar problems individually is certainly essential, but in today's ever more connected world, we are frequently called upon to collaborate to reach our objectives, both in our professional and personal lives. Working as part of a team has numerous advantages: it allows one access to an array of different points of view and experiences; synergies between groups members are created; and finally, it is possible to divide work or distribute tasks according to each member's strengths. However, collaboration can also present many difficulties. If the division of labor is not effective, two group members could find themselves doing the same task. Interpersonal tension and bad communication inside the group could also impede its potential. They are not innate; however with time and practice, collaborative competencies can be

\footnotetext{
1 We read in French: "La capacité à résoudre individuellement des problèmes non familiers est certes essentielle, mais dans notre monde de plus en plus interconnecté, nous sommes souvent amenés à collaborer pour atteindre nos objectifs, tant dans notre vie professionnelle que privée. Le travail en équipe présente de nombreux avantages : il permet de disposer de tout un éventail de points de vue et d'expériences; des synergies peuvent se créer entre les membres du groupe; et enfin, il est possible de procéder à une division du travail et à une répartition des tâches en fonction des points forts de chacun. La collaboration peut toutefois aussi présenter son lot de difficultés. Si la répartition des tâches n'est pas efficace, deux membres du groupe peuvent se retrouver à effectuer le même travail. Des tensions interpersonnelles et une mauvaise communication au sein du groupe peuvent également l'empêcher d'exploiter pleinement son potentiel. Si elles ne sont peut-être pas innées chez tous, les compétences de collaboration peuvent néanmoins se développer avec le temps et la pratique. C'est pourquoi l'enquête PISA 2015 a décidé d'étendre son investigation au-delà de la résolution individuelle de problèmes et de mesurer - pour la toute première fois dans une évaluation internationale - la capacité des élèves à collaborer pour la résolution de problème ». The Ministry of Education Report can also be consulted, Steve May (November, 2017, related to the results of the PISA 2015: Collaborative Problem-Solving, which included an assessment of their collaborative problem-solving abilities and attitudes towards cooperation. We read: "Collaborative problem-solving is the way in which an individual works with others to solve a problem, by establishing and maintaining a shared understanding of group organization." This report summarizes the results for New Zealand.

https://www.educationcounts.govt.nz/publications/series/2543/pisa-2015/pisa-2015-collaborative-problem-solving
} 
developed. It is for this reason, therefore, that PISA 2015 decided to expand its research beyond individual problem-solving to measure, for the first time in an international assessment, students' ability to collaborate in problem-solving" (t.n.).

Having made these clarifications (which are further developed in an article currently in press), we must highlight the fact that collaboration supposes a previous attitude, a willingness to work within this line of action. One is not born with this willingness; it is formed and consolidated through instances of socialization.

And this attitude underlies collaborative work.

Cooperation and collaboration, in contexts of pleasant relationships, help to reinforce connections/bonds, generating support. Along with this, they consolidate resilience or the ability to cope with unexpected situations, increasing levels of adaptability and lowering levels of stress ${ }^{1}$.

In another study (Aparicio et al, 2010 a), we worked with $\mathrm{N}=100$ public employees (42 men and 58 women); in different work environments (public and temporary jobs); and with different hierarchies (intermediate bosses and employees), in the government of Mendoza, Argentina. The average age was 43 and average seniority was 16 years. As regards their level of education, $71 \%$ had reached the Higher Education level (completed or not) and the remaining $29 \%$ had reached lower levels. We used three tests: the Maslach Burnout Inventory (Maslach \& Jackson, 1986) and BM (Pines \& Aronson, 1988), both to measure burnout; and we also applied the Coping Strategies Questionnaire to measure coping (Frydenberg \& Lewis, 1996). A qualitative instance complemented the obtained results, which suggested possible "reasons" for burnout. The techniques used were lexicometric analysis and hierarchical evocation: additionally, in-depth interviews were carried out with individuals and key respondents, which helped thoroughly, analyze aspects such as expectations, goals, levels of satisfaction within the world of work, and relationships with peers and superiors, among other aspects. Results showed that State University employees, having had more education in the area of coping mechanisms, were better able to adapt to change and had lower levels of burnout. (cf. Aparicio, $2015 \mathrm{a}$ and b, vol. 2).

\subsection{Specific theoretical-methodological framework of the research}

Taking into account the interaction between individuals and organizations, which is the base of resilience, cooperation and collaboration, we adopted a strategy of macro-micro-meso-macro analysis for our research based on a systemic sui generis approach: subject and structure in sustained interaction (Aparicio 1978-2014, in particular 2005, $2007 \mathrm{a}$ and b, $2009 \mathrm{a}$ and b, 2011 c, d and e, 2012, 2013 c, 2014, Aparicio \& Cros, 2015 c, Silva \& Aparicio, 2015 a, b - the author's theory titled "The three dimensional spiral of sense" or "Theory of three interactive levels", 2015, a and b, published in English².

According to this strategy, the individual exists within a context which imposes structural restrictions but is not determinant (Boudon, 1973). This is a context with both conflicts and opportunities for academic and professional development, one which can both favor or diminish the possibility of overcoming socio-professional obstacles and seeing life projects played out in terms of personal/professional achievement.

It is within this ecosystem and from a dynamic perspective, full of "goings and comings" that education / training seems to be key for sustainable human and social development.

How can education help us to overcome sociocultural and economic obstacles? Precisely through training in / consolidation of new abilities that allow us to "learn to learn" under the new learning paradigm (Shön, 1992): today "to know" is valued, yet what is one "capable of doing with that knowledge", just as "knowing how to behave" and "knowing how to live together". Countries which lead the rankings demonstrate that here is where we find a key aspect of achievement.

\footnotetext{
1 It is also important to note that a previous comparative study carried out by Aparicio found interesting results. In this study, the author compared stress levels, burnout and coping mechanisms of secondary level educators (currently those most pressured by their context, with clear salary problems and general non-conformism/unrest because of daily environmental conditions) and Argentine university level educators (who are less pressured and have greater opportunities for professionalization). The findings show that burnout decreases notably when individuals are able to cope with adversity and have developed coping mechanisms; in this study, these correspond to the university educators (Aparicio et al, $2010 \mathrm{~b}$ ).

2 This approach was presented in 2005/2009 (theory of the "dialogue between man / world"); it was later called the theory of "complexity in action", taking into account the interrelationship between society, personality and culture which is at the heart of socialization
} (Aparicio, 2012). 
Objectives:

\section{Quantitative approximation}

- To understand which factors, among those most mentioned in the international literature, have a significant impact on student success, helping to prevent the extension of studies (base, structural, pedagogical-institutional, organizational and psychosocial factors, including resilience) (theoretical plan).

- To understand which sociocultural, psychosocial and organizational aspects are most frequently related to the performance of individuals who extend their studies, in order to recognize at risk populations and provide those responsible with the tools necessary to implement preventative measures. This applies not only to programs of study or evaluation systems, but also in particular to the adoption of new strategies which would encourage reflection on practice and which would lead to the construction / consolidation of collective and social competencies at the base of the learning system (transfer / intervention plan).

\section{Qualitative approximation}

- To understand the "reasons" that are at the root of this phenomenon of extension, a phenomenon which has become common at Argentine universities and around the world, and particularly to understand the role that cooperation and social and collective competencies play in effective learning (theoretical plan).

- To understand the role that education in collective competencies plays in the words of failure expressed by the actors themselves: the students.

General hypotheses:

- At the quantitative level: a) Psychosocial factors - including the ability to recover when faced with adversity, which is favored by both the cultural context and by socialization (family, classmates, the educational institution), as well as by educational organizations - once they are internalized, will generate profiles more inclined towards professional success. b) There exist spaces which are better at educating in collective competencies (here, specific study programs, university schools). In fact, Resilience and related sub factors are not innate: it is institutions / organizations which are responsible for forming and consolidating these (Aparicio, 2007 a and b; Petit \& Dubois, op. cit.).

- Qualitatively: among the dimensions that have an impact on failure, social and collective competencies are fundamental.

- Applied level: early tracking and the formation of education / prevention programs for the construction of new collective competencies would greatly impact both individual achievement and institutional quality.

Specific hypothesis:

- Using this investigation's approach, high levels of resilience (RESIL) - including cooperation, collaboration and related abilities - have a positive influence on academic success (RU).

3. Methodology: quantitative and qualitative. Here we focus particularly on the qualitative results.

3.1. The Sample: was made up of 229 individuals from six schools at the National University of Cuyo in Mendoza, Argentina (19852004) who were interviewed at home. These are individuals who have been registered at the University since 1985 and reregistered for the 2004 school year but who are absent to classes, considered "ghost" students. They are enrolled in programs at six schools: Philosophy and Letters (Education Science), Economy (Accounting, Management), Political and Social Science (Social Communication), Law, Medicine and Engineering (Civil, Industrial and Oil). From a total of 1880 individuals identified in the files, the real number of individuals interviewed (those whom we could locate) was $\mathrm{N}=229$.

\subsection{Techniques}

Quantitative level:

We used a semi-structured survey with open-ended questions which allowed actors to speak freely, interviews and tests specifically designed to measure variables of the study extension model (generally cited above), including psychosocial variables related to 
academic success (United Kingdom): strategies to "cope" with difficulties (Frydenberg \& Lewis, 1996); attributional styles (Seligman, 1991); motivational factors (Montero \& Alonso Tapia, 1992); and resilience (Henderson \& Milstein, 2003)1.

Let us now observe resilience, a factor which incorporates cooperation as a sub factor.

The Henderson and Milstein Questionnaire consist of three scales: Student (RESIALUM), Personnel -Administration and Teaching (RESIPERS), and Institutional (RESIFACU) - and six subscales which can be grouped into two sub dimensions. They are:

I. Mitigating risk: 1. Enrich social bonds; 2. Establish limits (Develop and implement coherent academic policies and procedures, articulate behavior expectations, express rules clearly in writing); 3 . Teach life skills (cooperation, conflict resolution, communication, involvement, commitment, problem-solving, decision-making, and stress management, among others).

II. Developing resilience: 1. Give affection and support, this is a crucial element; 2. Establish and transmit high and "realistic" expectations, hoping for the best (avoiding the use of labels and the notion of a glass ceiling on development); 3 . Provide opportunities for meaningful participation (putting students and institutional leaders in charge of problem-solving, decision-making and goal-setting).

As is easy to observe, strong bonds, cooperation and rewarding relationships occupy a central place here as a sub factor.

We have interpreted the variable academic success (VD) in both a broad and strict sense of the term. Here we only present an outline of the variables considered.\}

- Performance in the broad sense of the term includes the following categories: a) Success: finalizing the program of study (graduation), b) Delay: finalizing the program of study over a period of time longer than officially expected (late graduates), c) Failure: dropping some courses.

- The stricto sensu result was measured using the following data provided by the Statistics Department of the UNCuyo: a) Years registered in a program of study (2005 cohort), b) Program length according to each student's study plan (ANPLAN), c) Unsuccessful courses (MATPLAN-PASS), d) corresponding to the program of study and study plan to which the student belongs (MATPLAN), e) Number of failures (APLAZOS) and f) Successful courses (MATREUS).

Finally, all of the information gathered (both qualitatively and quantitatively) was triangulated. This is a significant contribution as the tools which have existed up until now generally only capture the phenomenon unilaterally, focusing on only one factor (resilience, coping, etc.) measured quantitatively.

Qualitative level:

We use the metric analysis of maintenance and lexis, which takes into account the frequency with which actors use words related to the published nodes. This analysis includes the elaboration of categories and subcategories that express actors' representations of problematic aspects that they consider central or peripheral regarding obstacles that they have encountered to progress and finally obtain their degree.

\section{Results}

4.1. Quantitative: These show the role that resilience plays in achievement / extending studies.

We must remember that the factor Resilience was measured using three scales: Student (RESIALUM), Personnel (RESIPERS) and Institutional (RESIFACU). For each of these three scales -Student, Personnel and Institutional- the average was concentrated in Category 3 , which indicates that Resilience training is "in its beginnings".

\footnotetext{
1 II faut noter que ces aspects ont étés soulignés comme des facteurs centraux pour les pays ou les étudiants ont les rendements les plus hauts (PISA, 2015). Le détail est abordé dans un autre article, ou émerge, aussi, comme facteur important « l'auto efficacité », de Bandura (1977; OECD, cit.). Dans œ questionnaire le regard « réaliste » sur soi-même est sur litem 2 (sous presse).

$\|$ convient de se rappeler que "Les tests PISA sont appliqués tous les trois ans. Ils examinent la performance des élèves de 15 ans dans des domaines thématiques clés et étudient également un large éventail de résultats éducatifs, parmi lesquels: la motivation des élèves à apprendre, la conception qu'ils ont d'eux-mêmes et leurs stratégies d'apprentissage" (t.n.).

http://www.oecd.org/pisa/pisaenespaol.htm/consulte 2 mai 2018
} 
This means that, in general terms, at all of the University's schools, the assessment of the institutions being capable of Resilience training for students, personnel and the institution is rather low. In addition, each institution has its own profile (identity), some seem to generate resilience in students, personnel and/or the institution itself, promoting cooperation and interaction among the system's diverse actors ${ }^{1}$ (Aparicio, 2009e , f ; 2013 a, b, 2016).

In other words, there do exist both spaces that generate resilience and cooperation, and institutional cultures (schools / sectors in our study) that promote its emergence: a) the creation of informal social networks that guarantee unconditional acceptance (Petit \& Dubois, 1998); b) the development of the ability to build strong, respectful and rewarding relationships to consciously comply with standards and limits; $c$ ) the ability to learn to learn, to solve problems through reflection on practices and subsequent step by step analysis, which leads to the construction of relationship abilities through the exchanging of past representations for new ones that refer to new, more effective models of action for individuals and for the organization.

Finally, it is important to note that among the factors observed in our model (base variables, pedagogical-institutional variables, structural variables, sociocultural variables and organizational variables), the psychosocial and organizational dimensions have been shown to have the greatest impact on academic success (lower rates of extending studies).

\subsection{Qualitative:}

At the qualitative level, we have already highlighted the techniques utilized: interviews, lexical-metric analysis and openended questions (introduced as part of the semi-structured survey which allowed actors to express their opinions and present their representations freely).

Using the responses given, we constructed nodes, categories and subcategories.

For the nodes, actors manifested aspects which, from their point of view, interfered notably with their possibility for progress. The expressions used are far from those which the media focuses on daily (economic factors, poverty, linguistic codes, ...)

On the contrary, they highlighted communication problems with professors and administrative personnel more than with their classmates, lack of collaboration, absence of a sense of cooperation, teacher-student interactions, indifference, problems to listen, lack of strong bonds and support from the institution through formal or extracurricular strategies (Aparicio, $2015 \mathrm{~d}$ ), weak group integration, fear of failure, lack of solidarity and tolerance, low levels of collaboration on daily tasks, little teamwork, rigidity, and the prioritization of disciplinary aspects, among others (François, 2000, Aparicio, $2009 a$ and $b)$.

Our results bring to the forefront one specific situation: according to the actors, despite today's valuation of cognitive and social / collective abilities (study and work plans), these dimensions have not come to occupy a central place, in spite of failure and unemployment followed by a lack of training and certification.

The implementation of programs that emphasize these aspects is critical. In this way, it would be possible to achieve better results in terms of efficiency and greater satisfaction. The institution, on the other hand, in the cited interplay of individual and meso context, would obtain benefits in terms of efficiency and quality (Aparicio, 2005, $2011 \mathrm{a}$ and b).

Finally, we must remember that each institution has a unique profile and identity in terms of collective /social abilities, strengths and gaps which could guide decision-makers to implement programs which prioritize reflection (Aparicio, 2009 a, b, 2 volumes, Silva \& Aparicio, 2015).

5. Discussion: These results represent a significant contribution in this context: they demonstrate the need to develop sources of resilience, strong social bonds and cooperation within academic and extra-academic institutions; abilities that will positively impact the development of individuals and organizations and the articulation between training systems and productive systems (Aparicio, 2005, 2007a, 2007b, 2011a and b, 2015 a, b).

\footnotetext{
1 We are unable to explain the typical profile of each School. To analyze the quantitative weight of each factor included in the research, see Aparicio, 2007a, volume 1.
} 
The influence that the context has is clear, especially in the qualitative analysis. Individual and context in constant interaction, which can either enrich or weaken both the individual and the context. Developing the capacity to promote cooperation, even in the face of contextual limits and resistance to change, is therefore a challenge for institutions.

\section{Conclusion}

An understanding of the influence of certain factors / dimensions in light of theories on success could encourage the consolidation of some non-disciplinary abilities, often neglected in our system, and the transformation of best practices.

In fact, it seems important to base the educational / academic system's "integrative" reforms on the results of this research, founded on empirical referents, going beyond the still existent divorce of policy and technical aspects, of theory and practice.

It is also important to recover relevance / pertinence as a criterion for quality of educational institutions: in fact, we must pay attention to workplace requirements in terms of competencies (not only disciplinary but also interdisciplinary). Institutions should prepare their students for the future workplace and for the future of work, work which requires conversion, taking into account the impact of robotization, artificial intelligence, information technologies and other new technologies.

The socio-economic and political scene is complex in this context of globalization. Changes create uncertainty and in order to cope with difficulties we must develop social, collective and disciplinary competencies for the continuous renovation of action models. But we should also consolidate resilience at both the individual and group level in order to promote adaptation to change and flexibility; to promote cooperation. "Collaborative work" is becoming more and more necessary in all areas (PISA, 2015, World Forum). The results, which reveal the importance of these abilities/competencies, are a challenge for educational institutions (of all levels) and for labor organizations.

\section{References}

[1] Agasisti, T. et al. (2018). "Academic resilience: What schools and countries do to help disadvantaged students succeed in PISA", OECD Education Working Papers, No. 167, OECD Publishing, Paris. http://dx.doi.org/10.1787/e22490ac-en

[2] Andreu-Andrés, M. A. (2016).Aprendizaje cooperativo o colaborativo: ¿Hay alguna diferencia en la percepción de los estudiantes universitarios? Revista Complutense de Educación, 27(3):1041-1060, July 2016, DOI 10.5209/rev_RCED.2016.v27.n3.47398

[3] Aparicio, M. (2005). Les facteurs psychosociaux en relation avec la réussite universitaire et professionnelle. 2e thèse de doctorat. Paris: Université René Descartes, Sorbonne.

[4] Aparicio, M. (2007a). Les facteurs psychosociaux à la base de la réussite universitaire et professionnelle : aspects psychologiques et organisationnels. HDR en Psychologie. Lille: Université de Lille3.

[5] Aparicio, M. (2007b). Mobilité et réussite universitaires et professionnelles. Du niveau macro au niveau micro. HDR en Sciences de l'éducation. Paris: Université Paris X, Nanterre.

[6] Aparicio, M. (2009 a). " La formation des enseignants: tableau de la situation en Argentine et perspectives dans le cadre de la coopération bilatérale ". Symposium International de l'IRPE (Institut de recherche sur les pratiques éducatives. Quand la formation des adultes s'invite au débat sur la formation des enseignants. Table ronde. Du 20 au 21 octobre, Université de Sherbrooke, Canada.

[7] Aparicio, M. (2009 b). Clôture. Symposium International de l'IRPE (Institut de recherche sur les pratiques éducatives) et de la CRCIE (Chaire de recherche du Canada sur l'intervention éducative. Quand la formation des adultes s'invite au débat sur la formation des enseignants. Université de Sherbrooke, Canada. Du 20 au 21 octobre.

[8] Aparicio, M. (2009 c). La demora en los estudios universitarios. Causas desde una perspectiva cuantitativa. Tome I. Mendoza: EDIUNC.

[9] Aparicio, M. (2009 d). La demora en los estudios universitarios. Causas desde una perspectiva cualitativa. Universidad Nacional de Cuyo. Tome II. Mendoza: EDIUNC.

[10] Aparicio, M. (2009 e). Conférence d'ouverture: Les trajectoires universitaires et professionnelles : entre formation et travail. Congrès de l'Ecole de Gestion : Nouvelles carrières. Nouvelles compétences, Faculté des Sciences de la gestion. Rouen, Université de Rouen. Du 13 au 14 mai. 
[11] Aparicio, M. et al. (2009 f). Transformations du travail : nouvelles problématiques, nouveau enjeux. I Congrès de l'École de Gestion: Nouvelles carrières. Nouvelles compétences. Rouen: Université de Rouen. Du 13 au 14 mai.

[12] Aparicio, M. et al. 2010 a. Burnout et Coping. Une analyse auprès d'universitaires argentins travaillant dans l'administration publique [Burnout and Coping. The Analysis by Academic Argentineans Working in the Public Administration]. XVI Congrès de l'AIPTLF, Lille, France.

[13] Aparicio et al, $2010 \mathrm{~b}$. Attentes des enseignants et burnout professionnel Une analyse en terrain argentin. XVI Congrès de l'AIPTLF. Université Catholique de Lille, France.

[14] Aparicio M. (2011 a). Table ronde 6. Las competencias sociales ¿las grandes ausentes en la formación secundaria y universitaria? Congreso Internacional de la Red Iberoamericana de Investigación sobre la Calidad de la Educación Superior (RIAICES), Portugal. Du 24 au 26 février.

[15] Aparicio, M. (2011 b). Table ronde 5. Factores psicosociales y "competencias sociales" vinculados a logro académico como parámetros de la Calidad de la Universidad. Un estudio en Argentina. Congreso Internacional de la Red Iberoamericana de Investigación sobre la Calidad de la Educación Superior (RIAICES), Portugal. Du 24 au 26 février.

[16] Aparicio, M. (2011 c). Professional Identity Crisis, Social Identity Crisis (Crises d'identités professionnelles, crises d'identités sociales). In Book of Abstracts $8^{e}$ Congrès de l'UES (Union Européenne de Systémique (UES), Vol. 1, p.31.

[17] Aparicio, M. (2011 d). Les trajectoires des étudiants, un jeu entre les sujets et leurs contextes institutionnels, In Book of Abstracts $8^{e}$ Congrès de l'UES (Union Européenne de Systémique (UES), Vol. 1.

[18] Aparicio, M. (2011 e). Teachers' Professional Development at University and High School: an Interactive Relationship between Subjects and Socio-institutional Contexts (Professionnalisation des enseignants à I'Université et dans le secondaire: Un jeu de sujet et contexte institutionnel au milieu de la crise). In Book of Abstracts $8^{\circ}$ Congrès de l'UES (Union Européenne de Systémique (UES), Vol. 1.

[19] Aparicio, M. (2012). Trajectoires universitaires/professionnelles et identité. In J. Clénet, Ph. Maubant et D. Poisson (Eds.). Formations et professionnalisations : à l'épreuve de la complexité. Paris: L'Harmattan, 195-229.

[20] Aparicio, M et al (2013 a). Stratégies pour faire faces aux obstacles et Rallongement des études à l'Université. Colloque International de Psychologie du Travail et des Organisations, PTO. Abidjam, décembre.

[21] Aparicio, M. (2013 b). La résilience ou sur l'importance des "compétences sociales " face à la réussite universitaire. Colloque International de Psychologie du Travail et des Organisations, PTO, Abidjam, décembre.

[22] Aparicio, M. (2013c). Formación de formadores y Profesionalización en Argentina: Un análisis de la situación macro-social, méso-institucional y su impacto sobre las trayectorias e identidad de los formadores. In: A. Arbós et P. Puig Calvó (Eds.). Universidad y Sociedad: Formación, Profesionalización y Validación de la Experiencia, Barcelona: Furtwangen Editores, 195- 209. Traduction de l'article Aparicio, M. (2009). La formation des enseignants en Argentine : Une analyse de la situation macro-sociale, méso-institutionnelle et son impact sur l'identité des enseignants. Symposium International de l'IRPE (Institut de recherche sur les pratiques éducatives). Du 20 au 21 octobre. Université de Sherbrooke, Canada.

[23] Aparicio, M. (2014 a). University Drop-Outs. A Systemic Play of Subjects, Institutions and Macro Contexts. Journal of Educational and Social Research Vol 4, No 2. ISSN 2239-978X (Print).

[24] Aparicio, M. (2015 a). Towards a sui generis Systemic Theory: The Three-Dimensional Spiral of Sense. A Study in Argentina Applied to Identity and Professionalization (Part I). Asian Academic Reseach Journal an Social Science and Humanities, 2(8), (December 2015), 246-282.I

[25] Aparicio, M. (2015 b). The Theory of the Three-Dimensional Spiral of Sense: An Application with special Reference to Identity and Professionalization in other Disciplinary Areas (Part 2). Asian Academic Research Journal of Social Sciences \& Humanities, 2(8), (December 2015), 194-245.

[26] Aparicio, M. \& Cros, F. (2015 c). Trajectoires et identités. Un avenir incertain pour les docteurs? Paris: L'Harmattan.

[27] Aparicio et al. (2015 d). Social Competences and Organisational Devices in their Relationship with of University Studens' Retention. In Carmo, M. (2015) (Ed.). Education Applications \& Developments 13. Portugal: InScience Press. Vol. II, Chapter 17, 185-195. 
[28] Aparicio, M. (2016 a). Resiliency, Professionalization and Identity. A Study in Relation to Achievement at University at the Light of a New Paradigm: The Spiral Three Dimensional of Sens. European Journal of Multidisciplinary Studies (EJIS), Jan-Apr., vol 4(2), 126-131.

[29] Argyris, C. (1982). Learning and Action: Individual and Organizational. San Francisco: Jossey-Bass. Cit. par Shön, op. cit.

[30] Argyris, C. \& Shön, D. (1982). Theory in Practice: Increasing Professional Effectiveness. San Francisco, JosseyBass. Learning and Action: Individual and Organizational. Cit. by Shön, op. cit.

[31] Bandura, A. (1977). Self-Efficacy. Toward an Unifying Theory of Behavioral Change, Psychological Review, 34, 2, 191-215.

[32] Becker, H. (1950). Les mondes de l'Art, Cit par R. Gaglio (2011), Sociologie de l'Innovation, Paris, PUF.

[33] Berlinger, L. (2017). Ré-invenver l'école. Paris: Fabert.

[34] Bernaud, J-L. \& C. Lemoine (2000). Traité de psychologie du travail et des organisations. Paris: Dunod.

[35] Bernoux, P. (1985). La sociologie des organisations. Paris: Le Seuil.

[36] Bolstanki, L. \& Thévenot, L. (1987). Les économies de la grandeur. Cahier du Centre d'études de l'emploi, $n^{\circ}$ 31, Paris: PUF.

[37] Bonis, J. (1982). Les organisations formants. Pourquoi et à quelles conditions ? Personnel, $n^{0} 129$, janvier, $6-$ 10.

[38] Boudon, R. (1973). L'inégalité des chances. La mobilité sociale dans les sociétés industrielles. Paris: PUF.

[39] Chernyshenko, O., M. Kankaraš and F. Drasgow (2018), "Social and emotional skills for student success and wellbeing: Conceptual framework for the OECD study on social and emotional skills", OECD Education Working Papers, No. 173, OECD Publishing, Paris. http://dx.doi.org/10.1787/db1d8e59-en

[40] CONICET (2017). STAN, Services de transfert d'haute technologie.

[41] Crozier, M. (1963). Le phénomène bureaucratique. Paris: Le Seuil.

[42] Crozier, M. (1979). La société bloquée. Paris: Le Seuil.

[43] Crozier, M. \& Friedberg, E. (1977). L'acteur et le système. Paris: Le Seuil.

[44] Edler, N. S. \& parker, J.D.A. (1990). Coping Inventory for Stressful Situations (CISS): Manual. Toronto, Canada: Multi-Health Systems.

[45] Edler, N. S., \& parker, J.D.A. (1994). Assessment of Multidimensional Coping: Task, Emotion, and Avoidance Strategies. Psychological Assessment, 6, 50-60. Coping Inventory for Stressful Situations.

[46] François, P.-H. (2000). Orientation, vie professionnelle et conseil individuel. In J-L. Bernaud \& C. Lemoine, Traité de psychologie du travail et des organisations, Paris, Dunod.

[47] Frydenberg, E. \& Lewis, R. (1996). ACS. Escalas de Afrontamiento. Adaptation J. Pereña \& N. Seisdedos. Madrid: TEA.

[48] Gaglio, G. (2011). Sociologie de l'innovation. Paris: PUF.

[49] Henderson, N. \& Milstein, M. (2003). Resiliencia en la escuela. Buenos Aires: Paidós.

[50] Koninckx, G. (2011) Dynamics of resiliency in human systems. Key factors and key players. 9th Congress of the EUS-UES, Bruxels, Belgique. Du 19 au 22 octobre. "Approche systémique de la diversité: Du savoir à la pratique - De la pratique au savoir ». Actes du 8e Congrès de I'Union Européenne de Systémique (UES) / Proceedings of the 8th Congress of the European Union for Systemics (EUS). Aussi dans Acta Europeana, $\mathrm{n}^{\circ}$ 1.

[51] Landier, M. (1991). Vers l'entreprise intelligente. Paris: Calmann-Lévy.

[52] Levy-Garboua, L. (1976). Les demandes de l'étudiant ou les contradictions de l'université de masse, Revue française de sociologie, 17-1, 53-80.

[53] Lazarus, R. (2000). Estrés y emoción. Manejo e implicaciones en nuestra salud. España, Bilbao: Desclée de Brouwer.

[54] Lazarus, R. S. \& Folkman, S. (1986). El estrés y procesos cognitivos. Barcelona: Martínez Roca.

[55] Lazarus, R. S., \& Folkman, S. (1984). Stress, Appraisal and Coping. New York: Springer.

[56] Mo, J. (2018), "Comment l'enquête PISA mesure-t-elle le compétences de collaboration des élèves?", PISA à la loupe, No. 77, OECD Publishing, Paris, http://dx.doi.org/10.1787/f357f15a-fr

[57] Montero, I. \& Alonso Tapia, J. (1992). Cuestionario Mape II. In J. Alonso Tapia. Motivación en la adolescencia. Madrid: UAM.

[58] OECD. PISA. http://www.oecd.org/pisa/pisaenespaol.htm/consultado 2 mai 2018 
[59] OECD. World Economic Forum "Futur of job report". https://www.infobae.com/educacion/2018/01/14/cualesson-los-paises-que-mejor-se-preparan-para-el-trabajo-del-futuro/ Consultado 2 de mayo 2018

[60] OECD (2017a). "Collaborative problem solving", PISA in Focus, No. 78, OECD Publishing, Paris, http://dx.doi.org/10.1787/cdae6d2e-en

[61] OECD (2017 b), "Collaborative schools, collaborative students", in PISA 2015 Results (Volume V): Collaborative Problem Solving, OECD Publishing, Paris, http://dx.doi.org/10.1787/9789264285521-12-en

[62] Petit, F. \& Dubois, M. (1998). Introduction à la psychosociologie des organisations. Paris: Dunod.

[63] PICTO 2016-2019-0008. Agence nationale de science, technologie et innovation, Argentine. Projet dirigé par M. Aparicio, intitulé "Trayectorias laborales, Satisfacción, Profesionalización e Identidad. Un estudio en la UNCuyo en distintos contextos organizacionales (científicos, docentes y administrativos)". Sous la direction de M. Aparicio.

[64] Puerta de Klinkert, M. P. (2002). Resiliencia. La estimulación del niño para enfrentar desafíos. Buenos Aires: Lumen.

[65] Seligman, M. (1991). El optimismo es una ventaja y un placer que se adquiere. Buenos Aires: Atlántida.

[66] Sansaulieu, R. (1997). Sociologie de l'entreprise : organisation, culture et développement. Paris: Presses de Sciences Po et Dalloz.

[67] Salais, R. (1989). L'analyse économique des conventions du travail. L'économie des conventions, Revue économique, 40(2), mars.

[68] Shön, D. (1983). The Reflexive Practitioner. New York: Basic Books.

[69] Shön, D. (1992). La formación de profesionales reflexivos. Hacia un diseño de la enseñanza-aprendizaje en las profesiones. Madrid: Paidós Ibérica.

[70] Tersacc, G. (de) (1992). Autonomie dans le travail. Paris: PUF.

[71] Raux, J-F. (1994). Management et mutations, Futuribles, mai, 9-26.

[72] Reynaud, J.D. (1989). Les règles du jeu. L'action collective et la régulation sociale. Paris: Colin.

[73] Segrestin, D. (1992). Sociologie de l'entreprise. Paris: Colin.

[74] Silva, A. M. \& Aparicio, M. (Eds.) (2015 b). International Handbook about Professional Identities. New York: Academic and Scientific Publishing.

[75] Vanistendael, S. \& Lecomte, J. (2000). Le bonheur est toujours possible : construire la résilience. Paris: Bayard.

[76] Veltz, P. \& Zarifian, P. (1989). Vers de nouveaux modèles d'organisation ?, Sociologie du travail, 1/93, 3-25. 